bargain at its modest price, and the knowledge it imparts stupendous - surely it is a must for all lovers of the countryside.

C. R. S. PITMAN

\title{
Collins Guide to the Sea Fishes of Britain and North-Western Europe, by B. J. Muus and P. Dahlstrom. Collins, $£ 2.95$
}

It is pleasant to be able to welcome the arrival of a book which is actually cheaper to buy than its appearance would suggest, despite copious colour illustrations. These, by the distinguished Danish illustrator Preben Dahlstrom, are undoubtedly the book's main attraction; they are some of the best of European fishes ever produced - accurate, correctly coloured, and suggesting the living fish. His presentation too is interesting. The whole fish is represented, and little vignettes show hooks, the species' food, the canned product, and occasionally witty little sketches, as of the wistful looking cat beneath a huge tunny!

As a result Bent Muus's text, ably translated by Dr Gwynne Vevers, is rather overshadowed but more space has been found for it than in the original Danish edition (by using smaller type), and the species accounts are longer. Dr Vevers has also updated the scientific nomenclature. Two minor errors here are Gadus morrhua, instead of G. morhua, for the cod and Gobius minutus for the very abundant sand goby where the Danish edition gave it (correctly) as Pomatoschistus minutus.

As a guide to the fish fauna of the coasts of Denmark this is as excellent a book as one could ask for, and it serves very well for North Sea fishes. But to claim that it is a valid guide for North-west Europe is a false pretence, for which the Danish publishers are responsible.

The four pages devoted to gobies show six species dealt with in detail and three others merely mentioned - but at least 16 species are found round the British Isles. Montagu's blenny, common in the western English Channel and on the western Irish coast, is dismissed in two lines of text, and the illustration is a parody of this beautiful little fish, owing a lot to Francis Day's (1881) widely-copied but inaccurate illustration. These examples could be multiplied many times over, but they serve to show that the book is far from adequate as a guide to the British fish.

A number of commercially exploited crustaceans and molluscs are included, also with excellent illustrations, and the book concludes with an account of the history of fishing and the development of fishing techniques - both interesting, and models of compression.

ALWYNE WHEELER

\section{Creating Habitat}

In The Sevenoaks Gravel Pit Reserve, (obtainable from Merriewood House, St Botolph's Road, Sevenoaks, Kent, 62p.) Jeffery Harrison describes a remarkable achievement (in which he was prime mover) in creating wildlife habitat - a conservation technique that becomes increasingly important as wild habitat, especially wetlands, disappear. With the agreement of the gravel-pit owners, volunteers started work in 1956, creating islands, sheltered bays and spits, and planting cover, with the result that - to take just one set of figures - the annual wildfowl usage in wildfowl days' for dabbling and grazing ducks went up from 6162 in $1956 / 57$ to 79,244 in 1973/74. Interesting rarities here included ospreys, hoopoes, waxwings, water pipit and whooper swans. All this in the midst of suburbia.

The operation was a joint one by the Wildfowlers' Association of Great Britain and Ireland and the Wildfowl Trust, and shows how conservationists and industry can co-operate. The rather nervous reaction of industry is revealed in the foreword by Lord Beeching, Chairman of Redlands, the owners, when he praises 'the reasonableness of the ardent conservationists who run this reserve'. Was he surprised? 